\begin{tabular}{|l|l}
\hline JURNAL & JURNAL \\
Pendidikan Dasar dan Keguruan \\
Volume 4, No. 1, 2020 \\
ISSN (print) : 2527-578X \\
ISSN (Print) $: 2715-6818$ \\
Homepage $\quad:$ http://journal.iaimsinjai.ac.id/index.php/JPDK \\
\hline
\end{tabular}

\title{
PENGELOLAAN PENDIDIKAN MULTIKULTURAL DI SMP NEGERI 5 MAKASSAR
}

\author{
Ichsan $^{1}$ \\ ${ }^{1}$ Universitas Pohuwato, Pohuwato, Indonesia \\ ichsan_syam@yahoo.com
}

\begin{abstract}
Abstrak
Tujuan penelitian untuk mengetahui gambaran perencanaan pendidikan multikultural dan mengetahui gambaran pelaksanaan pendidikan multikultural. Jenis penelitian deskriptif kualitatif. Teknik pengumpulan data melalui wawancara, observasi, dan dokumentasi. Teknik analisis data yaitu pengumpulan data, reduksi data, penyajian data, dan penarikan kesimpulan. Hasil penelitian menunjukkan bahwa perencanaan visi, misi dan tujuan sekolah telah dilakukan dengan baik, pelaksanaan pedoman sekolah telah menetapkan tata tertib siswa, petunjuk dan larangan dalam disekolah, serta pemberian sanksi bagi yang melanggar tata tertib, adanya beberapa keberagaman agama, etnis, dan jumlah siswa yang cukup banyak, proses penerimaan siswa baru tanpa melihat suku dan agama serta kegiatan ektrakurikuler untuk siswa, kurikulum sekolah terdapat mata pelajaran yang sesuai pendidikan multikultural, bidang pendidik dan tenaga kependidikan disekolah guru melaksanakan tugas dan tanggung jawab sebagai pendidik yang memotivasi, memfasilitasi, membimbing dan melatih siswa menjadi manusia berkualitas dan mampu mengaktualisasikan potensinya, bidang sarana dan prasana sekolah cukup memadai tetapi perlu pengadaan ruang kelas bagi siswa belajar pendidikan agama kristen dan buddha, budaya dan lingkungan sekolah berjalan dengan baik dilihat dari keseharian siswa, berbicara sopan santun dan menghormati dengan guru ketikan berbicara disekolah, peran serta masyarakat disekolah terjalin dengan baik dibuktikan dengan adanya masyarakat memakai fasilitas gedung sekolah, mengadakan rapat serta latihan barongsai bagi etnis cina.
\end{abstract}

Kata Kunci: Perencanaan Pendidikan, Pengelolaan Pendidikan Multikultural

\begin{abstract}
The research objective is to find out the picture of multicultural education planning and to know the description of multicultural education implementation. Type of descriptive qualitative research. Data collection techniques through interviews, observation, and documentation. Data analysis techniques are data collection, data reduction, data presentation, and drawing conclusions. The results of the study showed that the planning of the vision, mission and goals of the school had been carried out well, the implementation of the school guidelines had set student discipline, instructions and prohibitions in schooling, as well as giving sanctions for those who violated the code of conduct, some religious diversity, ethnicity, and the number of students which is quite a lot, the process of admission of new students regardless of ethnicity and religion as well as extracurricular activities for students, the school curriculum there are subjects that are suitable for multicultural education, the field of educators and teaching staff at school teachers carry out their duties and responsibilities as educators who motivate, facilitate, guide and guide training students to become qualified human beings and able to actualize their potential, the field of facilities and infrastructure of the school is quite adequate but needs to provide classrooms for students to learn Christian and Buddhist religious education, culture and school environment run well viewed from the daily lives of students, speaking politely polite and respectful to the teacher when speaking at school, the community's participation in the school is well established as evidenced by the existence of the community using school building facilities, holding meetings and training lion dance for ethnic Chinese.
\end{abstract}

Keywords: Educational Plan ; Multicultural Education Management. 


\section{Pendahuluan}

Paradigma pendidikan multikultural juga menjadi salah satu poin penting dari Undang Undang dan sistem pendidikan nasional tahun 2003 yang berbunyi bahwa pendidikan diselenggarakan secara demokratis, tidak diskriminatif dengan menjunjung tinggi Hak Asasi Manusia (HAM), nilai keagamaan, nilai kultural dan kemajemukan bangsa. (Undang-Undang RI No. 20 Tahun 2003 tentang Sisdiknas pasal 4 ayat 1). Di sinilah letak peran lembaga pendidikan untuk kembali mereformulasi dan merevitalisasi format dan perwajahan pendidikan agar tidak hanya mengedepankan indoktrinasi kognitif dan psikomotor dengan mengabaikan aspek afektif peserta didik (Sudirman, 2019: 8)

Indonesia adalah salah satu negara yang multikultural terbesar didunia. Kebenaran dari pernyataan ini dapat dilihat dari sosio kultur maupun geografis yang begitu beragam dan luas. Dengan jumlah yang ada diwilayah NKRI sekitar kurang lebih 13.000 pulau besar dan kecil, dan jumlah penduduk kurang lebih 200 juta jiwa, terdiri dari 300 suku yang menggunakan hampir 200 bahasa yang berbeda. Selain itu juga menganut agama dan kepercayaan yang beragam seperti Islam, Katholik, Kristen Protestan, Hindu, Buddha, Konghucu, serta berbagai macam kepercayaan Yaqin (2005: 3). Keragaman ini diakui atau tidak, akan dapat menimbulkan berbagai macam persoalan seperti yang sekarang ini dihadapi bangsa ini. Seperti korupsi, kolusi, nepotisme, premanisme, perseteruan politik, kemiskinan, kekerasan, separatisme, Perusakan lingkungan dan hilangnya rasa kemanusiaan untuk selalu menghargai hak-hak orang lain adalah bentuk nyata dari multikultural itu. Contoh kongkrit terjadinya tragedi pembunuhan besar-besaran tehadap pengikut partai PKI pada tahun 1965, kekerasan etnis cina di Jakarta pada bulan mei 1998 dan perang antara islam dan Kristen di maluku utara pada tahun 1999-2003.

Berdasarkan permasalahan seperti diatas maka pendidikan multikultural menawarkan satu alternatif melalui penerapan strategi dan konsep pendidikan berbasis pemanfaatan keragaman yang ada dimasyarakat. Khususnya yang ada pada siswa seperti: keragaman etnis, budaya, bahasa, agama, status sosial, gender, kemampuan umur dan ras. Walaupun pendidikan multikultural merupakan pendidikan relatif baru di dalam dunia pendidikan.

SMP Negeri 5 Makassar menjadi sampel dalam penelitian ini. Lembaga pendidikan sekolah favorit di bawah naungan pemerintah dalam hal ini dinas pendidikan kota makassar sebagai peyelengara proses pendidikan di semua sekolah yang ada dikota makassar, didalamnya terdapat keberagaman multikultural dan sangat heterogen.

SMP Negeri 5 Makassar sebagai lembaga sekolah favorit dan juga di bawah naungan pemerintah dan dinas pendidikan, didalamnya terdapat keberagaman dan sangat heterogen. Dugaan ini berdasarkan pengamatan dan wawancara. Dengan kepala sekolah, beliau mengatakan bahwa siswa yang menuntut ilmu di SMP Negeri 5 Makasar terdiri dari berbagai macam etnis, suku, agama dan budaya. Sehingga dengan adanya keberagaman dan perbedaan kultural tersebut rentan terjadinya perselisihan dan konflik dalam interaksi di lingkungan sekolah tersebut.

Berdasarkan pada rumusan masalah diatas, maka tujuan penelitian yang ingin kami capai yaitu untuk mengetauhi gambaran perencanaan pengelolaan pendidikan multikultural di SMP Negeri 5 Makassar ditinjau dari visi, misi, dan tujuan sekolah dan untuk mengetauhi gambaran pelaksanaan pengelolaan pendidikan multikultural di SMP Negeri 5 makassar ditinjau dari pedoman sekolah, bidang kesiswaan, bidang kurikulum, bidang pendidik dan tenaga pendidikan, bidang sarana dan prasarana, budaya dan lingkungan sekolah, dan peran serta masyarakat dan kemitraan sekolah. 


\section{Metode}

Penelitian ini merupakan penelitian deskriptif kualitatif yang merupakan metode penelitian yang berusaha mengembangkan, mengambarkan dan mengiprestasikan objek dengan memperhitungkan konteks yang relevan dengan fenomena-fenomena yang realistis dilapangan. Penelitian ini mengambil lokasi di SMP Negeri 5 Makassar yang berlokasi di jl. Sumba kelurahan Pattunuang Kec.Wajo. lokasi ini dipilih dengan pertimbangan bahwa sekolah ini adalah sekolah yang menjunjung tinggi segala bentuk keanekaragaman baik etnis maupun agama.

Adapun yang menjadi sumber data atau informan utama dalam penelitian ini adalah 1 ( satu) orang kepala sekolah, 1 (satu) orang wakil kepala sekolah, 4 (empat) orang wakil kepala sekolah, 1 (satu) orang guru pendidikan agama, 1 (satu) orang guru PKN, 1 (satu) kepala TU, 4 (empat) orang siswa, dan 1 (satu) komite sekolah.

Setelah dilakukan pengumpulan data melalui wawancara dan studi dokumen, digunakan teknik analisis data menurut Miles dan Huberman dalam Sugiyono (2008: 92) mengemukakan beberapa aktivitas yang ditempuh dalam menganalisis data yaitu: Pengumpulan data (data collection), Reduksi data (data reduction), Penyajian data (Data Display) dan Verifikasi (Conclusion). Untuk mengabsahkan data yang ada, digunakan teknik pengabsahan data melalui triangulasi dan member check

\section{Hasil dan Pembahasan}

Gambaran perencanaan pendidikan multikultural di tinjau Visi sekolah SMP Negeri 5 Makassar "Unggul, berprestasi, berkarakter, dan berwawasan global berdasarkan imtaq". Dari visi tersebut, dapat dijelaskan bahwa sekolah memprioritaskan keunggulan peserta didik dalam mencapai prestasi dalam skala nasional maupun internasional, religius yang berlandaskan menurut kepercayaan agama masing-masing. Dikatakan oleh kepala sekolah SMP Negeri 5 Makassar Visi sekolah dirumuskan untuk menggambarkan harapan-harapan yang menjadi sasaran yang akan dicapai masa depan yaitu menjadi sekolah unggulan dikota Makassar, berkarakter dan berbudaya dengan berlandaskan nilai-nilai keagamaan masing-masing. (wawancara dengan MM tanggal 13 Mei 2013). Dari rumusan visi bahwa SMP Negeri 5 Makassar ingin mencapai unggul dalam memperoleh hasil ujian, unggul dalam lomba bidang studi, unggul dalam kedisiplinan, unggul dalam tatakrama serta unggul dalam hal keagamaan dan karakter bangsa.

Gambaran perencanaan pendidikan multikultural di tinjau Misi sekolah. Dalam mewujudkan visi SMP Negeri 5 Makassar perlu ditetapkan misi SMP Negeri 5 Makassar. Dengan pernyataan misi diharapkan seluruh warga sekolah dan pihak yang berkepentingan dapat mengetauhi dan mengenal keberadaan dan peran sekolah dalam meyelenggarakan pendidikan. Adapun misi sekolah tersebut sebagai berikut :

a. Melaksanakan pembelajaran dan bimbingan secara efektif, sehingga setiap peserta didik dapat berkembang secara optimal, sesuai potensi yang dimiliki.

b. Menumbuhkan semangat keunggulan secara intensif kepada seluruh warga sekolah

c. Meningkatkan intensitas dan kualitas pembelajaran sehingga setiap siswa memiliki kompetensi dan daya saing ke sekolah lanjutan

d. Memelihara budaya sekolah yang dilandasi norma agama, tradisi, kebiasaan keseharian yang dipraktekkan oleh semua warga sekolah.

e. Menumbuhkan penghayatan terhadap ajaran agama yang dianut dan budaya bangsa, sehingga menjadi sumber kearifan dalam bertindak. 


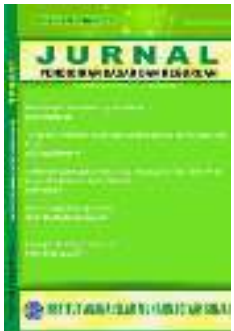

JURNAL

Pendidikan Dasar dan Keguruan

Volume 4, No. 1, 2020

ISSN (print) : 2527-578X

ISSN (Print) : 2715-6818

Homepage $\quad:$ : http://journal.iaimsinjai.ac.id/index.php/JPDK

Dari rumusan tersebut terlihat jelas bahwa misi SMP Negeri 5 Makassar bertujuan untuk mengembangkan pendidikan multikultural dengan melihat aspek pengelolaan. Sehubungan dengan prosedur penyusunan misi sekolah maka menurut kepala sekolah SMP Negeri 5 Makassar bahwa Prosedur penyusunan dan pengembangan visi dan misi sekolah dilakukan dengan mekanisme berupa rapat bersama yang melibatkan pihak internal dan eksternal sekolah. (hasil wawancara dengan MM tanggal 13 Mei 2013).

Pernyataan kepala sekolah tersebut telah menunjukkan bahwa rumusan misi yang ada saat ini merupakan kesepakatan bersama seluruh warga sekolah dengan beberapa pihak stakeholder sekolah lainnya. Senada dengan pernyataan tersebut, seorang wakil kepala sekolah yang cukup senior terlibat langsung dalam penyusunan visi, misi, dan tujuan sekolah menyatakan bahwa dalam rangka penyusunan visi dan misi SMP negeri 5 Makassar dalam kepemimpinan kepala sekolah (Drs. Martan Marzuki M.Pd) membentuk tim serta mengundang berbagai pihak luar yang ahli dalam bidang pendidikan untuk menyusun misi sesuai dengan sejarah dan kondisi lingkungan sekolah masa yang akan datang dalam mewujudkan sekolah unggulan.(hasil wawancara dengan RS tanggal 14 Mei 2013). Hal ini menunjukkan bahwa perumusan visi dan misi melibatkan seluruh komponen sekolah dan pihak stakeholder yang konsen terhadap dunia pendidikan dengan melihat aspek sejarah, lingkungan serta kondisi sekolah yang unggul, berprestasi, berkarakter, dan berwawasan global dan imtaq.

Gambaran perencanaan pendidikan multikultural di tinjau Tujuan sekolah SMP Negeri 5 Makassar. Selain visi dan misi sekolah juga menyusun tujuan yang akan dicapai. Tujuan tersebut disusun menjadi rujukan dalam mengembangkan program sekolah. Dijelaskan oleh kepala sekolah SMP Negeri 5 Makassar mengatakan "Selain visi dan misi sekolah, maka SMP Negeri 5 Makassar memiliki tujuan sekolah dalam mencapai visi dan misi yang telah di rumuskan dalam mengembangkan program sekolah" (wawancara dengan MM tanggal 14 Mei 2013).

Perumusan tujuan sekolah dilakukan untuk mencapai visi dan misi sekolah bertujuan untuk menjadikan sekolah unggulan yang berbudaya dan religius. Selanjutnya dari dokumen yang ada dalam menemukan rumusan tujuan SMP Negeri 5 Makassar berupa :

a. Perolehan hasil ujian akhir nasional (UAN).

b. Mampu berkompetensi dalam lomba bidang studi di tingkat propinsi.

c. Memiliki kerja kelompok ilmiah remaja dan mampu menjadi finalis di tingkat propinsi.

d. Memiliki tim kesenian yang mampu menjadi finalis di tingkat propinsi.

e. Lulusan yang lanjut ke sekolah unggulan minimal $40 \%$.

f. Memiliki tim olah raga yang mampu menjadi finalis di tingkat propinsi.

g. Memiliki siswa yang disiplin, bertatakrama yang baik, aktif dalam kegiatan keagamaan, dan peduli terhadap lingkungannya.

h. Memiliki kelompok yang aktif dalam menangulangi bahaya narkoba dilingkungan sekolah.

Tujuan sekolah yang disusun merupakan arah atau keadaan yang akan dicapai sekolah dalam jangka waktu pendek dan menengah. Kedepalan tujuan sekolah tersebut secara jelas menggambarkan bahwa sekolah ini menetapkan target pencapaian mutu dengan visi dan misi sebagai sekolah unggulan yang berbasis budaya dan agama.

Gambaran pelaksanaan pendidikan multikultural ditinjau dari pedoman sekolah, bidang kesiswaan, bidang kurikulum, bidang pendidik dan tenaga pendidikan, sarana dan prasarana, budaya dan lingkungan sekolah, dan peran serta masyarakat. . Pedoman sekolah termuat pada Tata tertib sekolah. Dalam proses pembinaan dan pengembangan pendidikan disekolah di perlukan pedoman 


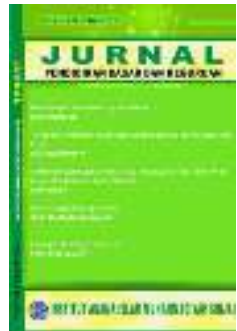

JURNAL

Pendidikan Dasar dan Keguruan

Volume 4, No. 1, 2020

ISSN (print) : 2527-578X

ISSN (Print) : :2715-6818

Homepage $\quad:$ : http://journal.iaimsinjai.ac.id/index.php/JPDK

bertindak bagi seluruh warga sekolah. Tata tertib harus dilaksanakan dan ditaati disekolah. Prosedur tata tertib dalam sekolah Wakil Kepala Sekolah SMP Negeri 5 Makassar mengatakan "Di SMP Negeri 5 Makassar tata tertib yang diterapkan terdiri dari beberapa prosedur, antara lain: penyusunan tata tertib siswa, pelaksanaan tata tertib siswa, pelanggaran tata tertib siswa" (wawancara dengan RS tanggal 16 Mei 2013). Pemaparan tersebut diartikan penyusunan tata tertib memperhatikan empat aspek yaitu: mengacu pada nilai-nilai dasar, tata tertib dibuat melibatkan semua unsur mulai dari guru, pegawai sekolah, kepala sekolah, siswa, dan orang tua siswa, penyusunan tidak sama dengan sekolah lain, dan sebelum ditetapkan masing-masing perwakilan menandatangai persetujuan tata tertib, termasuk pelaksanaan tata tertib dan pelanggaran.

Bidang pendidik dan tenaga pendidik, dalam wawancara dengan informan wakil kepala sekolah SMP Negeri 5 Makassar diruang kerja sekolah mengenai jumlah pendidik dan kualifikasi pendidikan mengatakan "Jumlah guru tenaga pendidik di SMP Negeri 5 Makassar berjumlah 51 orang guru terdiri dari 43 guru berstatus PNS dan 8 guru tidak tetap (Non PNS). Selanjutnya kualifikasi pendidik 4 orang guru s2, 43 guru s1, dan 4 orang guru D3" (wawancara dengan RS tanggal 21 Mei 2013). Berdasarkan dokumen yang kami temukan jumlah guru mata pelajaran sudah memenuhi kebutuhan dalam 1 mata pelajaran berjumlah 3 orang guru baik guru tetap maupun non PNS dan data tingkat kualifikasi menunjukkan belum memenuhi kondisi ideal sebab hanya terdapat 4 orang guru telah memiliki kualfikasi s2, 43 orang guru masih kualifikasi s1, dan 4 orang guru kualifikasi D3. Selanjutnya dalam tenaga kependidikan dan kualifikasi di SMP Negeri 5 Makassar kepala tata usaha mengatakan "jumlah tenaga kependidikan disekolah berjumlah 14 orang terdiri dari 7 orang berstatus PNS, 7 orang Non PNS, masing-masing memiliki kualifikasi 8 orang berstatus pegawai tetap dan 6 orang berstatus tidak tetap" (wawancara dengan SF tanggal 21 Mei 2013). Dari data tersebut jumlah staff tata usaha TU 8 staff, 3 orang satpam dan 3 orang sebagai cleaning servis di sekolah. Pemenuhan jumlah tenaga kependidikan menjadi kekuatan sekolah untuk melaksanakan berbagai kegiatan terutama administrasi siswa dan guru sehingga pelayanan dapat dilakukan secara maksimal

Bidang kurikulum, salah satu dimensi yang tidak bisa dipisahkan dari pembangunan dunia pendidikan di sekolah adalah kebijakan mengenai kurikulum. Kurikulum merupakan jantungnya dunia pendidikan. Untuk itu, kurikulum di perlu dirancang, dikembangkan, dan dikelola oleh pihak sekolah untuk meningkatkan mutu pendidikan di sekolah tersebut. Pengembangan kurikulum tersebut harus berpedoman kepada (1) Undang-Undang Nomor 20 Tahun 2003 tentang Sistem Pendidikan Nasional, (2) Peraturan Pemerintah Nomor 19 Tahun 2005 tentang Standar Nasional Pendidikan, (3) Permendiknas Nomor 22 Tahun 2006 tentang Standar Isi, (4) Permendiknas Nomor 23 Tahun 2006 tentang Standar Kompetensi Lulusan, dan (5) Permendiknas Nomor 24 Tahun 2006 tentang Pelaksanaan Permendiknas Nomor 22 dan 23. Dijelaskan oleh wakil kepala sekolah bidang kurikulum SMP Negeri 5 Makassar bahwa " Pengembangan kurikulum di SMP Negeri 5 Makassar mencakup (1) pengembangan program tahunan dan program semester, (2) pengembangan Silabus dan Rencana Pelaksanaan Pembelajaran (RPP), (3) pengembangan bahan ajar (4) program mingguan dan harian, (5) Penyusunan Kriteria Kemampuan Minimal, (6) program pengayaan dan remedial, (7) program bimbingan dan konseling, dan (8) Ujian Tengah semseter dan Ujian Semester "(hasil wawancara dengan PR tanggal 24 juni 2013). Hal ini menunjukkan pengembangan kurikulum ini disusun dengan memperhatikan semua aspek yang tertuang dalam standar pengelolaan pendidikan Selanjutnya komponen mata pelajaran terbagi tiga komponen yaitu mata pelajaran, muatan lokal, dan pengembangan diri. Berdasarkan wawancara wakil kepala bidang kurikulurm SMP Negeri 5 Makassar mengatakan "Jumlah mata pelajaran di SMP Negeri 5 Makassar berjumlah 10 mata 
pelajaran yaitu : pendidikan agama, PPKn, bahasa Indonesia, bahasa inggris, matematika, IPA, IPS, penjaskes, dan teknologi informasi \& komunikasi. Selanjutnya Muatan lokal yaitu : bahasa daerah dan keterampilan. Khsusus pengembangan diri adalah kegiatan yang bertujuan memberikan kesempatan kepada Siswa untuk mengembangkan bakat dan minat mereka sesuai dengan kemampuan sekolah. Kegiatan pengembangan diri dibimbing oleh Konselor dan Guru mata pelajaran. Pengembangan diri dilaksanakan dalam bentuk kegiatan Ekstrakurikuler yang ada di SMP Negeri 5 Makassar" (wawancara dengan PR tanggal 24 Juni 2013). Berdasarkan pemaparan tersebut kurikulum yang diberlakukan disekolah kurikulum KTSP yang dirancang sesuai kebutuhan peserta didik tingkat SMP, kompenen juga terbagi tiga mulai dari komponen mata pelajaran, muatan lokal, dan pengembangan diri.

Bidang kesiswaan, peneliti mewawancarai wakil kepala sekolah bidang kesiswaan Rukiah S.Pd atas bantuan informan dari kepala sekolah mengenai jumlah siswa pada tahun ajaran 2012/2013 dari kelas VII, VIII, dan IX, selanjutnya jenis kelamin siswa, keberagaman siswa, dan etnis atau suku siswa. Dari pertanyaan kami ajukan beliau mengatakan "jumlah keseluruhan orang siswa mulai dari kelas VII sampai kelas IX berjumlah 1.290 orang siswa dengan rincian kelas VII berjumlah 472 orang siswa, kelas VII berjumlah 440 orang siswa, dan kelas IX berjumlah 378 orang siswa. Selanjutnya berdasarkan jenis kelamin laki-laki berjumlah 604 orang, dan perempuan berjumlah 686 orang. Siswa yang belajar di sekolah ini beragam. Diantaranya adalah adanya agama islam, kristen protestan, kristen katolik dan budhha selanjutnya siswa berasal dari etnis makassar, bugis, toraja, cina, jawa dan luwu jadi siswa cukup beranekaragam" (hasil wawancara dengan R tanggal 27 Mei 2013). Untuk lebih jelas dapat dilihat pada tabel berikut ini keadaan jumlah siswa, gambaran keberagaman agama dan etnis pada siswa.

Tabel 1 keadaan Jumlah Siswa SMP Negeri 5 Makassar

\begin{tabular}{|c|c|c|c|c|}
\hline \multirow{2}{*}{ No. } & \multirow{2}{*}{ Kelas } & \multicolumn{2}{|c|}{ Nama Style } & \multirow{2}{*}{ Jumlah } \\
\hline & & $\mathrm{L}$ & $\mathrm{P}$ & \\
\hline 1. & VII & 205 & 267 & 472 \\
\hline 2. & VIII & 206 & 234 & 440 \\
\hline & IX & 193 & 185 & 378 \\
\hline \multicolumn{2}{|c|}{ Jumlah } & 604 & 604 & 1.290 \\
\hline
\end{tabular}

(Sumber : Bagian Tata Usaha SMP Negeri 5 Makassar)

Tabel 2 Gambaran Keberagaman Agama Pada Siswa Tahun Ajaran 2012-2013

\begin{tabular}{llc}
\hline No & Kelompok Agama & Jumlah \\
\hline 1. & Islam & 1.200 \\
2. & Kristen Protestan & 40 \\
3. & Kristen Katolik & 30 \\
4. & Buddha & 20 \\
Jumlah & $\mathbf{1 . 2 9 0}$ \\
\hline
\end{tabular}

(Sumber : Bagian Tata Usaha SMP Negeri 5 Makassar)

Tabel 3 Keberagaman Etnis Pada Siswa Tahun Ajaran 2012-2013

\begin{tabular}{llc}
\hline No & \multicolumn{1}{c}{ Nama Etnis } & Jumlah \\
\hline 1. & Makassar & 1.160 \\
2. & Bugis & 50 \\
3. & Cina & 51 \\
\hline
\end{tabular}




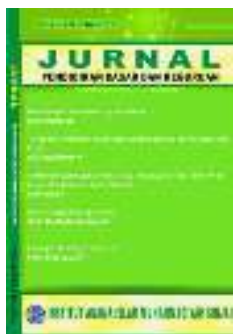

JURNAL

Pendidikan Dasar dan Keguruan

Volume 4, No. 1, 2020

ISSN (print) : 2527-578X

ISSN (Print) : :2715-6818

Homepage $\quad:$ : http://journal.iaimsinjai.ac.id/index.php/JPDK

$\begin{array}{lc}4 . \quad \text { Jawa } & 11 \\ 5 . \quad \text { Luwu } & 18 \\ \text { Jumlah } & \mathbf{1 . 2 9 0}\end{array}$

(Sumber :Bagian Tata Usaha SMP Negeri 5 Makassar)

Berdasarkan data tersebut keanekaragaman multikultural berjalan dengan baik ditandai dengan jumlah siswa begitu banyak perbedaan laki -laki dan perempuan lebih dominan perempuan disamping itu siswa yang berbeda keyakinan begitu heterogen dan etnis yang cukup beragam yang ada di SMP Negeri 5 Makassar.

Bidang Sarana dan prasarana, dalam pelaksanaan sarana dan prasarana di SMP Negeri 5 Makassar ini, peneliti mengadakan tanya jawab kepada wakil kepala sekolah bidang sarana dan prasarana mengatakan "Kondisi sekolah memiliki gedung berlantai 3 yang masih memiliki cagar budaya peninggalan belanda terdapat masing-masing ruangan yaitu 19 ruang kelas, 1 ruang TU, 1 Ruang kepala sekolah, 1 ruang wakil kepala sekolah, 1 ruangan didalam terdapat ruang wakil kurikulum dan kesiswaan, 1 ruang wakil kepala sarana dan prasana, 2 ruang guru, 1 ruang BK, 1 ruang perpustakaan, 1 ruang sangar seni, 1 ruang pramuka, 1 ruang PMR, 1 ruang musholla, 4 ruang WC, 1 ruang kantin, 1 panggung, 1 ruang lab, dan 1 ruang lapangan serbaguna" ( hasil wawancara dengan AS tanggal 08 Juni 2013).

Budaya dan lingkungan sekolah, budaya sekolah yang baik akan mendorong seluruh anggota masyarakat sekolah untuk meningkatkan kinerjanya agar tujuan sekolah dapat tercapai. Nilai, moral, sikap dan perilaku siswa selama di sekolah dipengaruhi oleh struktur dan kultur sekolah, serta interaksi mereka dengan aspek-aspek dan komponen yang ada di dalamnya, seperti kepala sekolah, guru, materi pelajaran dan hubungan antarsiswa sendiri. "Mengembangkan dan menerapkan secara konsisten nilai-nilai, aturan, filosofi dan kebiasaan-kebiasaan perilaku warga sekolah, dan tindakan yang ditampilkan dan ditunjukkan oleh seluruh warga sekolah dalam mencapai tujuan sekolah yang telah ditetapkan. Budaya dan lingkungan sekolah ini mengikuti sesuai visi dan misi sekolah yaitu displin, upacara bendera, komunikasi antar guru dan siswa, senam pagi, keimanan, kebersihan, dan keindahan "(hasil wawancara dengan RS tanggal 29 Juni 2013). Berdasarkan penjelasan tersebut SMP Negeri 5 Makassar budaya dan lingkungan sekolah sudah berjalan dengan baik.

Peran serta masyarakat dan kemitraan sekolah, Tujuan komite sekolah di SMP Negeri 5 Makassar Mewadahi dan menyalurkan aspirasi dan prakarsa masyarakat dalam melahirkan kebijakan operasional dan program pendidikan di satuan pendidikan. Meningkatkan tanggung jawab dan peran serta masyarakat dalam penyelenggaraan pendidikan di satuan pendidikan.dan Menciptakan suasana harmonis, akuntabel, dan demokratis dalam penyelenggaraan dan pelayanan pendidikan yang bermutu di satuan pendidikan. Wawancara dengan wakil kepala sekolah SMP Negeri 5 Makassar mengatakan "keberadaan komite sekolah di SMP Negeri 5 Makassar sebagai mitra antara orang tua murid dengan kepala sekolah dan guru-guru. Tetapi dalam keberadaan sekarang dalam 5 tahun terakhir pengurus tidak aktif" (hasil wawancara dengan RS tanggal 1 juli 2013).

\section{Simpulan}

Berdasarkan hasil penelitian dan pembahasan tentang pengelolaan pendidikan multikultural di SMP Negeri 5 Makassar, maka dapat disimpulkan bahwa perencanaan pengelolaan visi, misi, dan tujuan sekolah di SMP Negeri 5 Makassar telah dilakukan dengan baik, ditandai dengan kepala sekolah mengundang seluruh komponen sekolah dan pihak stakeholder yang konsen terhadap dunia pendidikan dengan menetapkan target pencapaian mutu sebagai sekolah unggulan yang berbasis budaya dan agama, 


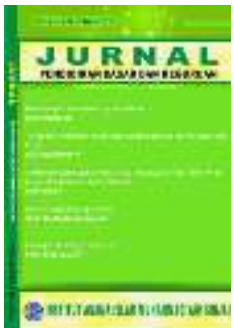

JURNAL

Pendidikan Dasar dan Keguruan

Volume 4, No. 1, 2020

ISSN (print) : 2527-578X

ISSN (Print) : 2715-6818

Homepage $\quad:$ : http://journal.iaimsinjai.ac.id/index.php/JPDK

Pelaksanaan pengelolaan pendidikan multikultural di SMP Negeri 5 Makassar yaitu pedoman sekolah dalam hal tata tertib SMP Negeri 5 Makassar sudah terlaksana dengan baik, dilihat dari aturan untuk siswa, sanksi, dan penghargaan demi kedisiplinan siswa dan guru disekolah; bidang kurikulum dalam pelaksanaan pendidikan multikultural terdapat mata pelajaran diantarannya mata pelajaran pendidikan agama islam dan Kristen, PPKn, Bahasa daerah serta keterampilan; bidang kesiswaan SMP Negeri 5 Makassar cukup beragam di sekolah bermacam-macam suku siswa yaitu suku Makassar, Bugis, Cina, Jawa, Toraja, dan Luwu, kemudian dari keanekaragaman agama siswa yaitu agama islam, Kristen katolik, Kristen protestan, hindu, dan budha. Sedangkan penerimaan siswa baru tahun ajaran 2013/2014 melalui tes kompetensi dengan jumlah yang diterimah 360 siswa; bidang tenaga pendidik guru sudah menjalankan tugas sebagai pendidik dengan baik, dengan indikator guru tidak hanya dalam mengajar wilayah kognitif, tetapi juga afektif dan psikomotorik, yaitu sikap saling menghargai, toleransi, terbuka dalam berfikir, membangun kepercayaan, dan saling membutuhkan; bidang sarana dan prasarana yang ada di SMP Negeri 5 Makassar ini belum bisa dikatakan sangat memadai, tetapi dari struktur gedung bangunan memang sudah lumayan memadai, namun masih ada sarana dan prasarana yang belum ada diantaranya sarana ibadah bagi non muslim dan penambahan ruang kelas; Bidang budaya sekolah sudah berjalan dengan baik dilihat dari masuk siswa sampai pulang sekolah, berbicara sopan santun, dan menghormati dengan guru ketika berbicara disekolah; Bidang mitra sekolah SMP Negeri 5 Makassar sudah terjalin dengan baik antara pihak sekolah dengan masyarakat sekitar bahkan gedung sekolah sering di pakai rapat warga dan latihan barongsai..

\section{Daftar Pustaka}

Akdon, (2009). Strategic Management for Educational Management. Bandung: Alfabeta.

Asy'ari, M. (2004). Pendidikan Multicultural dan Konflik Bangsa,Yogyakarta: http://kompas.com/kompas-cetak/0409/03/opini/1246546).

Azra, A. (2000). Pendidikan Islam: Tradisi dan Modernisasi Menuju Milenium Baru. Jakarta: Logos Wacana Ilmu.

Choirul, M. (2006). Pendidikan Multikultural. Yogyakarta: Pustaka Pelajar

Dawam, A.(2003). Emoh Sekolah. Yogyakarta: Inspealahimas Karya Press.

Depdiknas. (2001). Manajemen Peningkatan Mutu Pendidikan Berbasis Sekolah. Jakarta: Depdikbud Depdiknas. (2007). Standar Pengelolaan Pendidikan Oleh Satuan Pendidikan Dasar Dan Menengah. Jakarta: Depdikbud

Harsoyo. (1977). Manajemen Kinerja. Jakarta: Persada

Imron, A. (2002). Kebijaksanaan Pendidikan Di Indonesia. Jakarta: Bumi Aksara,

Kartono, K. (2004). Sistem Pendidikan Nasional. Jakarta: Pradnya Paramita.

Mariyana, R. (2010). Pengelolaan Lingkungan Belajar. Jakarta: kencana prenada Media Grup

Mas'ud, A. (2003). Menggagas Format Pendidikan Nondikotomik. Yogyakarta: Gama Media.

Moleong, L. (2012). Metode Penelitian Kualitatif. Jakarta:PT. Remaja Rosda Karya.

Muhyi, B. (2004). Sosiologi pendidikan. Jakarta: Ciputat Press.

Sudirman P. (2019). Peranan Pendidikan Dalam Menumbuhkan Kecerdasan Emosional Anak. Journal Pendidikan Dasar dan Keguruan, Vol. 1, No. 1, 2019. IAI Muhammadiyah Sinjai.

Sudjana, N. 2008. Dasar-Dasar Proses Belajar Mengajar. Bandung: Sinar Baru Algesindo 


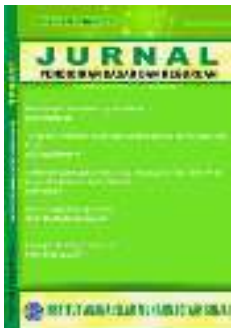

JURNAL

Pendidikan Dasar dan Keguruan

Volume 4, No. 1, 2020

ISSN (print) : 2527-578X

ISSN (Print) : 2715-6818

Homepage : : http://journal.iaimsinjai.ac.id/index.php/JPDK

Sudrajat, A. 2008. Wacana Pendidikan Multikultural Di Indonesia. http://akhamdsudrajat. Wordpress.com/04/04. Diakses tanggal 9 April 2013

Sugiyono. 2011. Metode Penelitian Kuantitatif, Kualitatif, dan R\&D. (cetakan ke-13). Bandung: Alvabeta. 